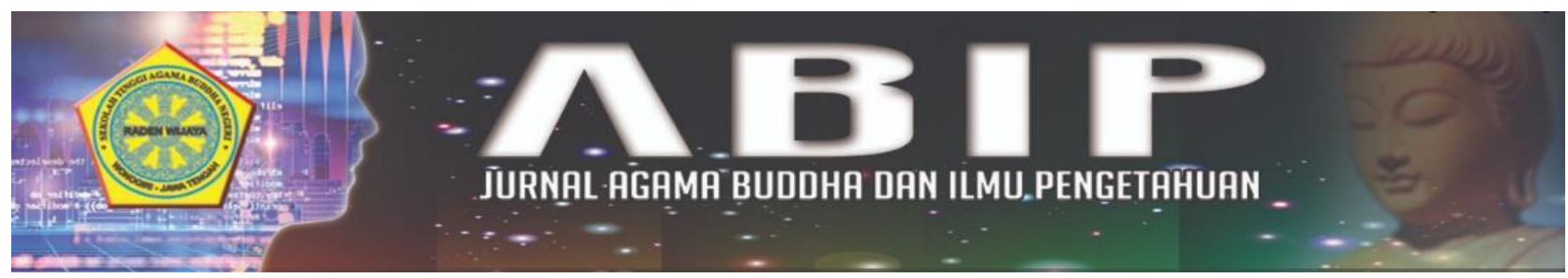

\title{
ETIKA AJARAN AGAMA BUDDHA UNTUK MEMBANGUN BANGSA DAN NEGARA DALAM KEBERSAMAAN
}

\author{
Arif Muzayin Shofwan \\ Universitas Nahdlatul Ulama (UNU) Blitar \\ arifshofwan2@gmail.com
}

\begin{abstract}
Abstrak
Penelitian ini mengkaji etika ajaran agama Buddha untuk membangun bangsa dan negara dalam kebersamaan. Metode yang digunakan adalah kajian kepustakaan dengan menggali data dari beragam buku bacaan yang sesuai dengan topik yang dikaji. Hasil dari kajian ini dapat dijelaskan sebagaimana berikut. Pertama, ada tiga etika paling urgen dalam ajaran agama Buddha untuk membangun bangsa dan negara, antara lain: etika pimpinan negara, etika politisi dan legislatif, dan etika penegak hukum dan media. Apabila tiga etika tersebut sudah terealisasi, maka bisa merambah pada etika berikutnya, antara lain: etika tokoh agama, para profesional, dan usahawan, etika reformasi sosial, etika menjalin kebersamaan, etika reformasi sosial, etika berhadapan dengan oposisi, etika pendidikan dan keilmuan, etika pengelolaan lingkungan hidup, dan etika bermusyawarah. Kedua, tujuan dari beragam etika berbangsa dan bernegara adalah untuk mewujudkan kehidupan harmonis dalam kebersamaan., antara lain: keharmonisan dalam disiplin moral, pandangan, berbagi keuntungan, perbuatan, ucapan, dan pikiran.
\end{abstract}

Kata Kunci: Etika, Agama Buddha, Bangsa, dan Negara

\begin{abstract}
This study examines the ethics of Buddhist teachings to build the nation and state in togetherness. The method used is a literature review by digging data from various reading books that are in accordance with the topic being studied. The results of this study can be explained as follows. First, there are three most urgent ethics in the teachings of Buddhism to build the nation and state, among others: the ethics of state leaders, the ethics of politicians and legislators, and the ethics of law enforcement and the media. If the three ethics have been realized, it can be expanded to the next ethics, including: ethics of religious leaders, professionals, and entrepreneurs, ethics of social reform, ethics of building togetherness, ethics of social reform, ethics of dealing with opposition, ethics of education and science, ethics environmental management, and deliberation ethics. Second, the purpose of the various ethics of the nation and the state is to create a harmonious life in togetherness, including: harmony in moral discipline, views, sharing profits, deeds, words, and thoughts.
\end{abstract}

Keywords: Ethics, Buddhism, Nation, and State 


\section{PENDAHULUAN}

Istilah "etika" menurut para pakar memiliki banyak makna atau arti. Jerkily (1964: 7) menyatakan bahwa etika berasal dari kata "ethos" berarti kebiasaan, adat. Sedangkan Preisker (1985: 201) mengartikan etika sebagai kebiasaan, kegunaan, adat, peraturan, kultus, dan hukum. Etika berhubungan erat dengan kelakuan manusia dan cara manusia melakukan perbuatannya. Kelakuan yang dinyatakan perbuatan itu menunjukkan pada dua hal, yakni positif dan negatif . Pengertian baik menunjuk pada hal yang baik. Sedangkan pengertian negatif menunjuk kepada hal yang jahat dan tidak baik. Etika hendak mencari ukuran baik, sebab yang tidak baik atau yang tidak sesuai dengan ukuran baik itu adalah buruk atau jahat (Brotosudarmo, 2007: 5). Oleh sebab itu, tugas etika adalah menyelidiki, mengontrol perbuatan-perbuatan, mengoreksi dan membimbing serta mengarahkan tindakan yang seharusnya dilakukan agar dapat memperbaiki tindakan atau perbuatannya (Poedjawijatna, 1977: 25-26).

Sementara itu, menurut Kamus Umum Bahasa Indonesia dijelaskan bahwa etika merupakan bagian ilmu pengetahuan tentang akhlak atau moral (Poerwodarminta, 1986: 278). Tak jauh dari hal tersebut, Brownlee (1987: 16) menyatakan bahwa istilah etika ditinjau dari segi makna atau arti hampir sama dengan istilah moral. Tetapi dalam pemakaian ilmiah, moral biasanya hanya menyangkut kebaikan atau keburukan secara lahiriah atau kelihatan dari apa yang sebenarnya terjadi. Sedangkan etika adalah suatu perbuatan yang dilakukan dengan sengaja sebagai hasil keputusan yang tegas berdasarkan analisa dan olahan akal budi yang menyangkut pemikiran sistematik tentang kelakuan, motivasi dan keadaan batin yang menyadarinya. Dengan demikian, etika lebih dalam artinya daripada moral. Etika lebih umum dan memandang kaidah-kaidah atau norma-norma serta merupakan ilmu dinamis (Darmaputera, 1987: 5-6).

Dalam konteks kajian ini, membangun bangsa dan negara dalam kebersamaan tentu saja memerlukan etika. Ada banyak etika ajaran agama Buddha untuk membangun bangsa dalam kebersamaan. Mahasthavira (2013: 19) menyatakan bahwa etika dan sila dalam agama Buddha adalah panduan untuk dapat menimbulkan harmoni dalam hati dan pikiran. Ciri etika dan sila adalah ketertiban dan ketenangan. Fungsi etika dan sila adalah mengarahkan kelakuan yang salah agar menjadi benar dan menjaga seseorang agar tetap tidak berada dalam sikap salah. Wujud etika dan sila adalah kewaspadaan dan pengendalian yang diwujudkan pada saat berfikir, berucap, dan berbuat. Tujuan etika dan sila adalah kemurnian, kebaikan, dan kebenaran berkehidupan. Perkembangan etika dan sila adalah malu berbuat jahat (hiri) dan takut akibat perbuatan jahat (ottapa). Keduanya ini adalah pelindung dunia. Jika tidak ada keduanya, manusia akan berkecamuk dalam kekacauan yang merugikan dirinya sendiri maupan masyarakat lainnya.

Lanjut Mahasthavira (2013: 16) bahwa etika merupakan dasar kehidupan berbangsa dan bernegara. Etika adalah barometer peradaban bangsa. Etika menjadi bagian dari kultur sosial dan antropologis bangsa Indonesia. Yakni, konstruksi etika kebangsaaan yang berdasarkan Pancasila. Prinsip dan formulasi Pancasila adalah etika berbangsa dan bernegara yang religius, berperikemanusiaan, persatuan, demokrasi, dan keadilan. Dengan demikian, prinsip etika berbangsa dan bernegara yang berdasarkan Pancasila, apabila tidak dilaksanakan maka bangsa bagaikan kehilangan kompas dan negara tidak mempunyai haluan dan sasaran yang hendak dicapai. Sabda Sang Buddha terkait etika berbangsa dan bernegara sudah sangat jelas: "Negara yang mendambakan tiga macam kemuliaan, yaitu kemasyhuran, kemakmuran, dan kedamaian, hendaknya memegang teguh prinsip dan melaksanakan etika (sila)" (Khuddaka Nikaya, Silava Thera).

Berdasarkan uraian di atas, tujuan penelitian ini adalah sebagaimana berikut, antara lain: (1) untuk mengungkap etika-etika membangun bangsa dan negara dalam kebersamaan menurut ajaran-ajaran agama Buddha; dan (2) untuk mengungkap tujuan etika berbangsa dan bernegara tersebut diajarkan dalam agama Buddha. Dari dua 
tujuan tersebut diharapkan dapat menyumbang wawasan keilmuan Buddhis kepada para akademisi, guru, peneliti, dan masyarakat umum khususnya yang beragama Buddha.

\section{METODE PENELITIAN}

Tulisan kualitatif ini menggunakan studi kepustakaan (library research) dalam melakukan penelitiannya. Nazir (1998: 122) menyatakan bahwa studi kepustakaan adalah teknik pengumpulan data dengan mengadakan studi penelaahan terhadap buku-buku, literatur-literatur, catatan-catatan, dan laporanlaporan yang ada hubungannya dengan masalah yang dipecahkan. Menurutnya, studi kepustakaan merupakan langkah yang penting dimana peneliti menentukan sebuah topik kemudian melakukan kajian dengan topik yang sedang diteliti (Ibid, 122).

Tak jauh dari pengertian di atas, studi kepustakaan diartikan sebagai serangkaian kegiatan yang berkenaan dengan metode pengumpulan data pustaka mulai dari membaca, mencatat, serta mengolah bahan penelitian (Zed, 2003: 3). Dengan demikian, penelaahan buku-buku, bacaan-bacaan, dan catatan-catatan yang terkait dengan kajian penelitian ini merupakan sesuatu hal yang urgen. Sebab penggalian dari data-data terkait itulah yang akan menjadikan penelitian ini berhasil secara maksimal.

\section{ANALISIS KAJIAN}

\section{Etika Membangun Bangsa dan Negara Ajaran Buddha}

Sang Buddha banyak mengajarkan etika dalam membangun bangsa dan negara. Beberapa etika untuk membangun bangsa dan negara dalam kebersamaan tersebut ada yang berkaitan dengan etika pemimpin negara, penegak hukum, legislatif, politisi, rakyat biasa, dan semacamnya. Tentu saja, membahas dan mengkaji etika-etika tersebut menjadi sangat urgen bagi suatu bangsa dan negara dalam situasi dan kondisi seperti sekarang ini. Selain itu, mengkaji dan membahas hal tersebut mengandung banyak manfaat bagi umat Buddha. Ternyata Sang Buddha tidak hanya mengajarkan ajaran yang sifatnya hanya ke dalam diri belaka. Namun, beliau juga peka terhadap fenomena di luar diri, seperti kenegaraan, kebangsaan, dan semacamnya. Berikut pembahasan beragam etika dalam membangun bangsa dan negara menurut perspektif Buddhisme.

\section{Etika Pimpinan Negara}

Seorang pimpinan negara hendaknya memiliki etika-etika sebagai pimpinan. Seorang pimpinan negara hendaknya selalu memperbaiki dirinya, menguji tingkah lakunya dengan hati-hati dalam perbuatan, perkataan, dan pikiran, mencoba untuk mengetahui dan mendengarkan pendapat rakyat, dan lain sebagainya. Mahasthavira (2013: 22) mengutip Kitab Majjhima Nikaya yang menyebutkan sebagai berikut: "Raja (baca; pimpinan negara) selalu memperbaiki dirinya dan menguji tingkah lakunya dengan hati-hati dalam perbuatan, perkataan, dan pikiran, mencoba untuk mengetahui dan mendengarkan pendapat rakyat, seperti apakah dia telah melakukan kekurangan dan kesalahan dalam mengatur kerajaan (negara)-nya. Jika ternyata dia memerintah dengan tidak benar, rakyat akan mengeluh bahwa mereka merasa ditindas oleh penguasa yang buruk dengan perlakuan tidak adil, hukuman, pajak, atau segala bentuk korupsi, dan mereka akan bereaksi menentangnya dengan satu atau lain cara. Sebaliknya, bila dia memerintah dengan benar, mereka akan memberkatinya demikian, "semoga Yang Mulia panjang umur".

Selain itu, dalam hal etika atau moral bagi pimpinan negara, Mahasthavira (2013: 21-22) dengan mengutip Kitab Milinda Panha menyebutkan demikian: "Jika seseorang yang tidak sehat, tidak kompeten, tidak bermoral, tidak layak, tidak mampu, dan tidak berharga untuk kedudukan raja (konteks sekarang adalah presiden), telah menobatkan sendiri sebagai raja atau penguasa dengan otoriter besar, dia tentu akan menjadi sasaran hukuman oleh rakyat, karena dengan tidak pantas dan tidak berharga, dia telah menempatkan dirinya sendiri secara tidak benar dalam kursi kedaulatan. Penguasa, seperti siapapun yang melanggar kode moral dan peraturan dasar segala hukum sosial umat manusia, juga merupakan sasaran terhadap hukuman; dan lebih lanjut, terkecamlah penguasa yang bertindak sebagai perampok rakyat". Demikianlah hal-hal yang harus dihindari oleh pimpinan suatu negara dan bangsa. 
Tak jauh dari hal di atas, seorang pimpinan negara harus menjauhi sifat keserakahan, iri hati, dan kebohongan. Sebab pimpinan yang bisa melenyapkan sifat-sifat tersebutlah yang pantas disebut pimpinan yang arif bijaksana. Dalam Kitab Suci Dhammapada disebutkan: "Bukan hanya pandai bicara, dan bukan pula karena memiliki wajah bagus seseorang dapat menyebut dirinya orang baik, apabila dia masih bersifat iri hati, kikir, dan suka menipu. Tetapi, dia yang memotong, mencabut, dan memutuskan akar sifat iri hati, kekikiran, serta dusta, maka orang dia patut disebut orang baik" (Dhammattha Vagga, 262-263). Dengan demikian, etika pimpinan negara di antaranya adalah tidak iri hati, mengakui persaman hak, menolak diskriminasi, meningkatkan kondisi sosialekonomi, pemerataan kekayaan, tidak berbohong, tidak menjalankan pemerintahan dengan keserakahan, dan semacamnya.

Sementara itu, dalam kisah Jataka disebutkan bahwa Sang Buddha memberikan sepuluh peraturan bagi kepala negara yang baik, yang terkenal dengan sebutan "Dasa Raja Dhamma". Sepuluh etika bagi pimpinan negara tersebut, antara lain: (1) dana, yakni memberikan kesejahteraan kepada yang memerlukan; (2) sila, yakni memiliki moral yang tinggi; (3) paricagga, yakni bersedia mengorbankan semua kesenangan pribadi, nama dan keagungan, hingga nyawa demi kepentingan rakyat; (4) ajjava, yakni jujur dan bersih; (5) maddava, yakni ramah dan tidak bengis; (6) tapa, yakni mampu mengendalikan diri; (7) akkodha, yakni bebas dari kebencian; (8) avihimsa, yakni tanpa kekerasan; (9) khanti, yakni rendah hati dan sabar; dan (10) avirodha, yakni tidak bermusuhan (Widya, 2010: 20-22).

\section{Etika Politisi dan Legislatif}

Mahasthavira (2013: 20) menyatakan bahwa saat sekarang, banyak politisi berkuasa yang mereka sadari atau tanpa disadari kerap membuat pernyataan dan melemparkan isu yang menciptakan kegaduhan politik. Tingkah lakunya yang ditampilkan di media pun mengabaikan norma kesopanan publik. Kecenderungan tindakan mereka hanya untuk mengejar kepentingan pribadi, kekuasaan, pengaruh, mengabaikan tugas dan kewajiban utama mereka untuk membangun bangsa dan memakmurkan negara. Padahal, figur para pimpinan, politisi, menteri, dan pejabat seharusnya mampu memberikan suri tauladan kepada rakyatnya. Sebab bila semua itu bisa menjadi suri tauladan yang baik, maka imbasnya pun juga merambah pada yang dipimpinnya. Dalam Kitab Angguttara Nikaya, Sang Buddha pernah bersabda: "Jika penguasa suatu negara adil dan baik, para menteri menjadi adil dan baik, jika para menteri adil dan baik, para pejabat tinggi menjadi adil dan baik, jika para pejabat tinggi adil dan baik, para bawahan menjadi adil dan baik; jika para bawahan adil dan baik, rakyat menjadi adil dan baik".

Selanjutnya, terkait etika legislatif, Mahasthavira (2013: 20-21) menyatakan bahwa wakil rakyat dipilih oleh rakyat untuk tujuan membangun kesejahteraan rakyat. Bilamana wakil rakyat yang menjadi legislatif membuat peraturan yang justru menyengsarakan rakyat, berarti mereka telah mengkhianati kepercayaan yang diembankan oleh rakyat kepada mereka. Pembuat peraturan seharusnya memahami dan mematuhi peraturan, bukan malah sebaliknya melanggar peraturan. Tugas utama wakil rakyat seharusnya mengontrol tindakan pemerintah, bukan justru meminta jatah dari pemerintah. Wakil rakyat adalah panutan rakyat, semestinya tindakan mereka tidak memalukan rakyat. Mengetahui apa yang harus dilakukan adalah kebijaksanaan. Mengetahui bagaimana harus melakukan sesuatu adalah ketrampilan. Dapat melakukan sebagaimana mestinya adalah pelayanan.

Berkaitan dengan hal di atas, tampak dalam Kitab Majjhima Nikaya disebutkan lima penghidupan yang salah, antara lain: (1) hidup dengan jalan menipu orang lain; (2) membual dan menjilat; (3) memeras dengan menjilat dan memfitnah; (4) menggelapkan atau menyulap; dan (5) mengambil keuntungan yang salah/korupsi (Majjhima Nikaya 3, 75). Lima hal inilah yang harus dihindari oleh politisi dan legislatif guna membangun kehidupan bangsa dan negara dalam kebersamaan sebagai bagian dari etika Buddhisme. Untuk menegaskan beberapa etika bagi politisi dan legislatif tersebut, Mahasthavira (2013: 21) mengutip Kitab Suci Dhammapada 292 yang berbunyi: 
"Orang yang melakukan apa yang seharusnya tak dilakukan dan tak melakukan apa yang seharusnya dilakukan, maka kekotoran batin akan terus bertambah dalam diri orang yang sombong dan malas seperti itu".

\section{Etika Penegak Hukum dan Media}

Mahasthavira (2013: 23) mengutip

kisah Jataka yang menyebutkan bahwa penguasa atau hakim yang menghukum orang yang tidak bersalah dan tidak menghukum orang yang berbuat jahat, maka mereka tidak layak memerintah suatu negara. Dengan demikian, etika seorang penguasa atau hakim di antaranya adalah berhati-hati dalam memutuskan berbagai persoalan, berusaha memutuskan persoalan secara adil. Dalam Kitab Suci Dhammapada disebutkan: "Dia yang memutuskan segala sesuatu dengan tergesa-gesa, tidak dapat dikatakan orang yang adil. Orang bijaksana hendaknya memeriksa dengan teliti, mana yang benar dan mana yang salah. Dia yang mengadili orang lain dengan tidak tergesa-gesa, bersikap adil dan tidak berat sebelah, yang senantiasa menjaga kebenaran, dia pantas disebut orang yang adil" (Dhammattha Vagga, 256-257).

Selanjutnya penting pula membahas etika media yang saat ini terkadang terlalu vulgar dalam memberitakan kejahatan dan keburukan. Mahasthavira (2013: 24) menyatakan bahwa peran dan fungsi media elektronik maupun cetak saat ini bukan hanya sekedar menyampaikan berita, ilmu pengetahuan dan tayangan hiburan yang dirasakan masih kurang mendidik dan membangun moral bangsa. Untuk mencegah kekotoran batin masyarakat dan kerusakan mental para penonton, kiranya semua tayangan harus terlebih dahulu difilter, harus sesuai waktu dan kegunaannya. Media harus mengutamakan peran dan kontribusi untuk mendidik dan mendewasakan pikiran, mencerdaskan dan menumbuh kembangkan kebijaksanaan masyarakat.

Terkait etika media, baik elektronik maupun cetak, Mahasthavira (2013: 25) mengutip pepatah Tiongkok berikut: "Promosikan kebaikan orang di mana saja, sebaliknya berita keburukan orang jangan dipublikasikan". Hal tersebut mengandung maksud agar masyarakat tidak meniru keburukan, mereka harus selalu meniru dan belajar kebajikan, serta malu melakukan kejahatan. Lanjut Mahasthavira mengutip Kitab Majjhima Nikaya 2, 78 berikut: "Tidak menceritakan keburukan orang lain, sekalipun ditanya, apalagi jika tidak ditanya. Bila perlu berbicara, sepatutnya dikemukakan dengan hati-hati, inilah sikap bicara orang yang bijaksana. Selanjutnya, ditanya atau tidak ditanya selalu menceritakan kebaikan orang lain. Jika ditanya perlu untuk berbicara, sepatutnya memuji kebaikan orang lain tersebut dengan terus terang, tanpa keraguan dan jelas. Inilah arti dari perkataan bijaksana".

Demikianlah beragam etika yang menurut penulis paling urgen dalam membangun bangsa dan negara. Walaupun dalam hal tersebut masih banyak etika-etika yang harus dirajut, namun ketiganya di atas telah mencakup problem negara yang saat ini perlu dibenahi. Selanjutnya, rajutan etika bisa dikembangkan lagi ke arah yang lebih luas, sebagaimana etika-etika berbangsa dan bernegara yang disebutkan oleh Mahasthavira (2013: 20-28) sebagaimana berikut, antara lain: etika tokoh agama, para profesional, usahawan, dan lainnya. Selain itu, Mahasthavira juga menyebutkan beberapa etika lain, diantaranya: etika reformasi sosial, etika menjalin kebersamaan, etika reformasi sosial, etika berhadapan dengan oposisi, etika pendidikan dan keilmuan, etika pengelolaan lingkungan hidup, dan etika bermusyawarah. Menurut hemat penulis, rajutan etika yang disebutkan belakangan ini akan berjalan lancar apabila rajutan etika utama yang paling urgen di atas dapat berproses dengan baik dan benar.

\section{Tujuan Etika Buddhis Membangun Bangsa dan Negara}

Tujuan dari etika membangun bangsa dan negara sebagaimana yang tersebut di atas pada intinya adalah untuk mewujudkan kehidupan harmonis dalam kebersamaan. Mahasthavira (2011: 9) menyatakan bahwa keharmonisan berarti adanya keselarasan, keseimbangan, dan keserasian. Sebuah kebersamaan dibangun dari keharmonisan. Tanpa keharmonisan akan sulit terealisasikan kebersamaan yang positif, bermanfaat, dan saling menguntungkan. Menurut Mahasthavira (2011: 9) dinyatakan bahwa untuk 
menciptakan kebersamaan dalam kemanusiaan diperlukan enam prinsip keharmonisan sebagai berikut, antara lain:

1. Keharmonisan dalam disiplin moral, yakni harmonis dalam ketaatan dan kepatuhan pada kemoralan (sila), malu berbuat jahat, dan takut akan akibat berbuat jahat.

2. Keharmonisan dalam pandangan, yakni harmonis dalam pelatihan bersama berdasarkan pengertian yang sama.

3. Keharmonisan berbagi keuntungan, yakni harmonis dalam membagikan keberuntungan secara adil dan seimbang serta tidak merugikan.

4. Keharmonisan dalam perbuatan, yakni harmonis dalam perbuatan baik yang bermanfaat, saling melindungi, dan tidak melukai satu sama lainnya.

5. Keharmonisan dalam ucapan, yakni harmonis dalam ucapan yang bermanfaat, saling mengingatkan satu sama lainnya, saling menganjurkan melakukan kebaikan dan mencegah kejahatan.

6. Keharmonisan dalam pikiran, yakni harmonis dalam pikiran positif, bermanfaat dalam persahabatan, menghormati peran dan pengabdian masing-masing individu maupun kelompok.

Sebagai warga negara Indonesia tentu saja harus menyadari bahwa bangsa ini terbangun dari berbagai macam suku, agama, budaya, dan semacamnya. Oleh sebab itu, kebersamaan bersama harus dirangkai dalam perpaduan berbagai unsur yang harmonis. Mahasthavira (2013: 19) menyatakan bahwa bangsa Indonesia adalah bangsa yang multietnik, multikultural, dan multireligious. Keragaman tersebut merupakan karunia dan kekayaan tak ternilai yang dimiliki bangsa Indonesia. Keragaman tersebut perlu ditata dengan baik dan bijak, dikelola, dikreasi, dan dilestarikan dalam bingkai kesatuan untuk membangun perpaduan harmonis yang asri, tanpa diskriminasi, guna merajut masa depan peradaban luhur bangsa Indonesia yang berwarna-warni.

Lanjut Mahasthavira yang menyatakan bahwa adanya keragaman seperti itu merupakan kodrat alamiah yang telah mengakar dan sudah terjadi di muka bumi ini. Adapun bila terdapat adanya keseragaman itu merupakan sebuah bentukan dan produk atas kepentingan yang tidak alamiah. Dengan demikian, secara etis setiap warga Indonesia berkewajiban menghormati, bersinergi, dan melestarikan keragaman tersebut dalam bingkai Bhinneka Tunggal Ika. Yakni, walaupun berbeda entitas tetapi tetap manunggal, walaupun berbeda-beda tetapi tetap dalam bingkai persatuan. Realitas hal tersebut adalah kedudukan dan kewajiban setiap warga Indonesia adalah sederajat dan saling bahu-membahu dalam menjalani kehidupan yang bermanfaat, saling merangkul kebersamaan untuk mengisi pembangunan nasional.

Tak jauh dari hal di atas, Mahasthavira (2013: 9) menyebutkan bahwa kebersamaan umumnya dibentuk dari kesamaan pandangan visi dan misi yang berdasarkan motivasi pikiran terang dan seimbang. Secara normatif, kebersamaan yang langgeng hanya bisa dibentuk dan dilaksanakan apabila manusia telah terbebas dari keserakahan, kebencian, dan kebodohan. Hanya manusia arif yang memiliki belas kasih universal dan bekerja tanpa pamrih saja yang dapat menjalin kebersamaan secara utuh, lahir dan batin. Mereka ini secara tekun, ulet, dan gigih terus mengajarkan kebaikan untuk dunia. Mereka bagaikan lilin yang rela terbakar untuk menerangi kegelapan dunia.

Sementara itu, Saccapiyo (2016) dengan mengutip Kitab Anguttara Nikaya 11, 32 menyatakan bahwa Sang Buddha memerinci empat hal yang menunjang persahabatan dan kebersamaan. Pertama, dāna, yakni kerelaan atau pemberian. Pemberian tidak harus berupa materi, namun bisa berupa non-materi. Seseorang bisa memberikan senyuman, memberikan maaf, memberi sapaan yang baik, dan lainnya. Kedua, piyavācā, yakni ucapan yang baik dan halus. Ucapan yang baik dan halus bisa menyebabkan suasana persahabatan yang harmonis. Sedangkan ucapan yang buruk dan kasar bisa menyebabkan pertengkaran dan konflik. Ketiga, atthacariyā, yakni melakukan hal yang bermanfaat untuk orang lain. Perbuatan yang bermanfaat bagi orang lain dapat menimbulkan rasa persahabatan dan kebersamaan. Keempat, samānattatā, yakni tidak sombong. Sikap tidak sombong dapat 
menimbulkan kehidupan yang harmonis dalam kebersamaan. Sementara sikap angkuh dapat menimbulkan pertikaian dan permusuhan.

\section{KESIMPULAN}

Dari analisis kajian di atas dapat disimpulkan sebagaimana berikut, antara lain: Pertama, etika merupakan dasar kehidupan berbangsa dan bernegara. Etika adalah barometer peradaban bangsa. Tujuan etika dan sila adalah kemurnian, kebaikan, dan kebenaran berkehidupan. Perkembangan etika dan sila adalah malu berbuat jahat (hiri) dan takut akibat perbuatan jahat (ottapa).

Kedua, ketika membangun bangsa dan negara dalam kebersamaan terdapat beberapa etika paling urgen dalam perspektif Buddhisme yang harus direalisasikan sebagaimana berikut, antara lain: (1) etika pimpinan negara; (2) etika politisi dan legislatif; (3) etika penegak hukum dan media. Kemudian, setelah beberapa etika yang paling urgen tersebut direalisasikan, lalu bisa merambah beberapa etika yang lainnya.

Ketiga, beberapa etika lain yang harus dirajut dalam membangun bangsa dan negara dalam kebersamaan, antara lain: etika tokoh agama, para profesional, dan usahawan. Selain itu ada beberapa etika lain, diantaranya: etika reformasi sosial, etika menjalin kebersamaan, etika reformasi sosial, etika berhadapan dengan oposisi, etika pendidikan dan keilmuan, etika pengelolaan lingkungan hidup, dan etika bermusyawarah.

Keempat, tujuan dari beragam etika berbangsa dan bernegara pada intinya adalah untuk mewujudkan kehidupan harmonis dalam kebersamaan., antara lain: keharmonisan dalam disiplin moral, pandangan, berbagi keuntungan, perbuatan, ucapan, dan pikiran.

Kelima, ada empat hal yang menunjang persahabatan dan kebersamaan, antara lain: dāna, yakni kerelaan atau pemberian; piyavāca, yakni ucapan yang baik dan halus; atthacariyā, yakni melakukan hal yang bermanfaat untuk orang lain; dan samānattata $\overline{\text {, }}$ yakni tidak sombong.

\section{DAFTAR PUSTAKA}

1. Brownlee, Malcolm (1987). Pengambilan Keputusan Etis dan Faktor-Faktor yang
Ada di Dalamnya. Jakarta: BPK Gunung Mulia.

2. Brotosudarmo, Pdt. R.M. Drie S, S.Th., M.Th., M.Si (2007). Etika Kristen untuk Perguruan Tinggi. Yogyakarta: Penerbit Andi.

3. Darmaputera, Eka (1987). Perkenalan Pertama. Jakarta: BPK Gunung Mulia.

4. Dhammadhiro, Bhikkhu [penyaji], (2005). Paritta Suci: Kumpulan Pāli Wacana untuk Upacara dan Pūjā. Jakarta: Sangha Theravāda Indonesia.

5. Jerkily (1964). Etika Kristen Bagian Umum. Jakarta: BPK Gunung Mulia.

6. Mahasthavira, YM. Bhiksu Tadisa Paramita (2013). "Etika Berbangsa dan Bernegara dalam Perspektif Ajaran Buddha" dalam Harmoni, No. 25/01/IV/HAR/13.

7. ------ (2011). "Togetherness In Humanity (Kebersamaan dalam Kemanusiaan)" dalam Harmoni, No. 21/03/XI/11.

8. Nazir, Moh. (1998). Metode Penelitian.. Jakarta: Ghalia Indonesia.

9. Preisker, (1985). "Ethos" dalam Gerhard Kittel (ed). Teological Dictionary of The New Testament. Grand Rapids Mi: William Eerdmans Publishing Co and Paternoser Press.

10. Poedjawijatna (1977). Etika, Filsafat, Tingkah Laku. Jakarta: Obor.

11. Poerwodarminta, W.J.S (1986). Kamus Umum Bahasa Indonesia. Jakarta: Balai Pustaka.

12. Saccapiyo, Bhikkhu (2016). "Hidup Harmonis Dambaan Setiap Orang" dalam http://www.dhammacakka.org.

13. Tim Penulis (2005). Tipitaka Kitab Suci Agama Buddha Dhammapada Sabda Sabda Buddha Gotama. Jakarta: Lembaga Pengkajian dan Pengembangan Keagamaan Buddha Indonesia.

14. Widya, Dharma K. (2010). Penuntun Berorganisasi. Jakarta: DPD Pemuda Theravada Indonesia DKI Jakarta.

15. Zed, Mestika. (2003). Metode Penelitian Kepustakaan.. Jakarta: Yayasan Obor Indonesia 